\title{
Broad-range potential of Asphodelus microcarpus leaves extract for drug development
}

\author{
Amalia Di Petrillo', Antonella Fais ${ }^{1 *}$ D, Francesca Pintus ${ }^{1}$, Celestino Santos-Buelga², Ana M. González-Paramás², \\ Vincenzo Piras ${ }^{3}$, Germano Orrù ${ }^{3}$, Antonello Mameli ${ }^{3}$, Enzo Tramontano ${ }^{1}$ and Aldo Frau ${ }^{1}$
}

\begin{abstract}
Background: Many plants have been used in traditional medicine for their antibacterial, antifungal, antiprotozoal, antiviral, antidiarrhoeal, analgesic, antimalarial, antioxidant, anti-inflammatory and anticancer activities. In order to find novel antimicrobial and antiviral agents, the aim of the present study was the evaluation of the antibacterial and antibiofilm susceptibility of Asphodelus microcarpus leaves extract. Moreover, the antiviral activity and the phytochemical composition of the active extract were also determined.

Methods: Antimicrobial and antibiofilm activities of leaves ethanol extract of A. microcarpus were evaluated on 13 different microbial strains. We selected three different sets of microorganisms: (i) Gram-positive bacteria, (ii) Gramnegative bacteria and (iii) yeasts. The potential antiviral activity of $A$. microcarpus leaves ethanol extract was evaluated with a luciferase reporter gene assay in which the dsRNA-dependent RIG-I-mediated IFN- $\beta$ activation was inducted or inhibited by the Ebola virus VP35 protein. HPLC-DAD-MS was used to identify phenolic profile of the active extract.

Results: A. microcarpus leaves extract showed a potent inhibitory activity on Gram-positive bacteria while only a reduced inhibition was observed on Gram-negative bacteria. No activity was detected against Yeasts. The extract also showed an interesting antibiofilm motif on various bacterial strains (E. coli, S. aureus, S. haemolyticus and B. clausii). Moreover, this extract significantly affected the Ebola virus VP35 inhibition of the viral RNA (VRNA) induced IFN response.

Conclusions: The overall results provide supportive data on the use of A. microcarpus as antimicrobial agent and a potential source of anti-viral natural products.

Data collected set the bases for further studies for the identification of single active components and the development of new pharmaceuticals.
\end{abstract}

Keywords: Asphodelus microcarpus, Plant extract, Antibiotics, Biofilm, Antimicrobial activity, Antiviral response, Ebola virus

\section{Background}

The interest for plant extracts and derived compounds is significantly increased over the last years, in the attempt to identify new active substances with therapeutic properties $[1,2]$. Plants are rich in a wide variety of secondary metabolites such as tannins, terpenoids, alkaloids, flavonoids, glycosides, which have been found to have in

\footnotetext{
*Correspondence: fais@unica.it

'Department of Life and Environmental Sciences, University of Cagliari, Cittadella Universitaria, SS 554, Bivio per Sestu, I-09042 Cagliari, Monserrato, Italy

Full list of author information is available at the end of the article
}

vitro antimicrobial properties [3, 4]. In fact, they could be a good alternative to synthetic chemical antimicrobial agents and antibiotics, because of the serious side effects, antimicrobial resistance and the emergence of previously uncommon infections, which have been increasing due to inappropriate or widespread overuse of antimicrobials. There are several reports in the scientific literature describing the antimicrobial properties of crude extracts prepared from plants $[5,6]$ and recent studies have been carried out on their anti-biofilm activities against different types of microorganisms [7]. Biofilm is a complex matrix of microorganisms in which 
cells bind together and attach to biotic or abiotic surface $[8,9]$. It has been observed that biofilm formation is associated with many infectious diseases and is a major concern for immunocompromised patients [10] because it provides structural stability and protection to the bacteria, so that the entrapped bacteria become resistant against extreme environmental conditions (i.e. $\mathrm{pH}$, temperature and presence of antibiotics).

Plant extracts show many biological activities [11-14] and they stand as an infinite resource for drug development, novel pharmacophores, and scaffolds for amplification into efficacious drugs for a multitude of disease $[1,2]$.

A number of small molecules extracted from plants are known for their antiviral effects, while no antiviral drugs coming from plant constituents have been approved so far. For instance, flavonoids and anthraquinones showed inhibitory activity against Influenza A virus, Hepatitis C virus and HIV [15-20]. Defense mechanisms against invading pathogens are accurately controlled by both innate and adaptive immunity. The innate immune system, in particular, is crucial to initiate these anti-pathogen immune activities of the host organism. The type I interferon (IFN) system is a major player in antiviral defense against all kinds of viruses. Virusinfected cells synthesize and secrete IFN that stimulates susceptible cells to express potent antiviral mechanisms that limit further viral growth and spread [21]. However, highly pathogenic viruses such as Ebola virus (EBOV), developed a number of strategies for counteracting innate immune system responses [22, 23]. In particular, the EBOV VP35 protein is essential for viral inhibition of IFN production and, hence, it has been shown to be an effective viral target [23, 24]. Within this context, one approach to subvert this powerful immune response inhibition is to identify small molecules that potentiate or activate the IFN signaling pathway, increasing IFN production in response to viral infections to a level able to overturn this inhibition.

Mediterranean area offers a great variety of endemic plants in Europe and, due to its geographical isolation, the island of Sardinia provides an even greater plant biodiversity, with significant variations in genetic and molecular characteristics as compared to plants grown in other regions.

The primary benefit of plant-derived medicines is due to their availability, fewer side effects and reduced toxicity. Ethnopharmacological studies have shown that a number of them were used until less than 100 years ago in folk medicine [25] and some of them were reported to have therapeutic effects on inflammations and immune system reinforcements [26].

Asphodelus microcarpus Salzm.et Vivi (Asphodelaceae) is widely distributed over the coastal Mediterranean region and was traditionally used as an antimicrobial agent [27]. In ethnobotanical literature, its use for otitis and toothache in Algeria [28] and for lung diseases in Sardinia [29] has been also reported. Several studies were performed in order to verify its antimicrobial activity [30-32]. Recently, antimicrobial activity of areal part of A. microcarpus was evaluated on Propionibacterium acnes, implicated in the pathogenesis of acne vulgaris [33], and on methicillin resistant Staphylococcus aureus MRSA [34]. The methanolic extract of $A$. microcarpus leaves demonstrated a higher anitimicrobial activity against Staphylococcus aureus and Candida albicans [35].

A. microcarpus is traditionally used for the toothache and this prompted us to investigate the anti-biofilm activity and the potential antimicrobial activities of $A$. microcarpus leaves extract against oral and environmental bacteria frequently reported in dental unit water line (Streptococcus spp., Staphylococcus spp., Escherichia coli) [36].

Moreover, based on previous experiments described in different publications [37, 38], potential antiviral activity of $A$. microcarpus extract have been carried out.

\section{Methods}

\section{Plant collection}

Asphodelus microcarpus subsp. microcarpus Salzm. et Viv. (syn. Asphodelus ramosus L. subsp. ramosus) leaves were collected in southern Sardinia (Quartu Sant'Elena, Cagliari, Italy). The GPS coordinates were $39^{\circ} 22^{\prime} 41.5^{\prime \prime}$ $\mathrm{N}$ and $09^{\circ} 19^{\prime} 62.3^{\prime \prime} \mathrm{E}$. The plant was identified by Dr. Cecilia Loi, Department of Life and Environmental Sciences, Section of Botany, University of Cagliari, Italy. A voucher specimen (1405/16 Herbarium CAG) has been deposited in the Museum Herbarium CAG (Life and Environmental Sciences Department).

Plant materials were washed with deionized water, frozen at $-80{ }^{\circ} \mathrm{C}$ and then lyophilized. The dried plant was stored at $-80^{\circ} \mathrm{C}$ until required.

\section{Extraction procedure}

The lyophilized plant materials $(10 \mathrm{~g})$ were extracted in $50 \mathrm{~mL}$ of ethanol for $24 \mathrm{~h}$ at room temperature under continuous stirring. After filtration, ethanol extract was diluted 10-fold with water and then lyophilized (Asphodelus Extract, AE). Dried powder was dissolved in 10\% DMSO for antimicrobial activity tests. For HPLCDAD-ESI/MS analyses, dried extract was dissolved in $1 \mathrm{~mL}$ of $0.1 \%$ formic acid: acetonitrile $(70: 30, v / \mathrm{v})$ and filtered through a $0.22 \mu \mathrm{m}$ disposable LC filter disk for HPLC analysis.

\section{Microbial strains}

To evaluate the antimicrobial profile of $\mathrm{AE}, 13$ different microbial strains have been used. We selected three 
different sets of microorganisms: (i) Gram-positive bacteria, Staphylococcus aureus ATCC 6538 (American Type Culture Collection), Staphylococcus haemoliticus clinical isolate NC1, Streptococcus uberis human clinical isolate NC 20, Streptococcus faecalis ATCC 29212, Streptococcus mutans CIP103220 (Collection Institut Pasteur), Streptococcus salivarius, strain k12 (from a commercial product, Bactoblis ${ }^{\circ}$ ), Streptococcus pyogenes human clinical isolate NC4, Streptococcus intermedius DSMZ 20573 (German Collection of Microorganism and cell culture), Bacillus clausii, (isolated from a commercial product, Enterogermina ${ }^{\circ}$ ); (ii) Gram-negative bacteria, Escherichia coli ATCC 7075; (iii) Yeasts, Candida albicans, Candida kruseii, Candida glabrata, human oral clinical isolates, designed from BF1 to BF3 respectively. E. coli, B. clausii, S. haemolyticus and S. aureus were plated in Muller Hinton agar; Shaedler agar for Streptococci and Sabouraud dextrose agar for fungi. Prior to use, all the strains were stored in a tube containing the proper medium broth with $20 \%$ of glycerol at $-80{ }^{\circ} \mathrm{C}$. These microbial strains were used for an in vitro susceptibility test: (a) the agar diffusion method, (b) Minimal Inhibitory Concentration (MIC), (c) Minimum Bactericidal Concentration (MBC), which were determined in accordance with the National Committee for Clinical Laboratory Standards, NCCLS. In addition, the Minimal Biofilm Inhibitory Concentration (MBIC) was used to evaluate the AE antibiofilm activity [39].

\section{Antimicrobial susceptibility testing}

The Agar diffusion method was performed by using the Kirby-Bauer (KB) procedure and used as preliminary antimicrobial test to reveal the entire antimicrobial susceptibility profile for the examined AE. $1 \cdot 10^{7}$ cells $/ \mathrm{mL}$ were inoculated onto the surface of an agar plate containing one of the subsequent bacterial growth agar mediums (Microbiol, Uta, Italy): (i) Muller-Hinton agar for aerobic bacteria, (ii) Shaedler agar for Streptococcus spp., (iii) Fungi on Sabouraud agar. This antimicrobial activity test was performed following the NCCLS protocol by using a paper filter disc $(\varnothing=6 \mathrm{~mm})$ impregnated with AE work solution $(1000 \mu \mathrm{g} / \mathrm{mL})$. MIC and MBC were performed only in susceptible microbial strains with $K B$ test and they were performed according to the Micro-broth dilution method $[40,41]$ by using a $1 \frac{1}{2}$ serial dilution, from 500 to $3.9 \mu \mathrm{g} / \mathrm{mL}$ of the AE; the positive controls were performed with a Chlorhexidine digluconate solution (CHX), Sigma-Aldrich, ranged a concentration from 500 to $0.48 \mu \mathrm{g} / \mathrm{mL}$ (Table 1 ). The cultures were incubated in air at $37{ }^{\circ} \mathrm{C}$ for $24 \mathrm{~h}$ for the aerobic strains and in $5 \% \mathrm{CO}_{2}$ at $37{ }^{\circ} \mathrm{C}$ for the Streptococcal species. For the biofilm evaluation, we used the protocol described by Montana University's Center for Biofilm Engineering [42]. A microplate containing serial
Table 1 Antibacterial profile of A. microcarpus leaves extract on a set of different microorganisms

\begin{tabular}{llll}
\hline Strains & $\begin{array}{l}\text { Kirby-Bauer } \\
\varnothing \mathrm{mm}\end{array}$ & $\begin{array}{l}{ }^{\mathrm{a} M I C} \\
(\mu \mathrm{g} / \mathrm{mL})\end{array}$ & $\begin{array}{l}\mathrm{MBC} \\
(\mu \mathrm{g} / \mathrm{mL})\end{array}$ \\
\hline Gram-positive bacteria & $4 \pm 1$ & 250 & $>500$ \\
Bacillus clausii & $10 \pm 2$ & 250 & $>500$ \\
Staphylococcus aureus & $-\mathrm{b}$ & $-\mathrm{b}$ & $-\mathrm{b}$ \\
Streptococcus salivarius & $-\mathrm{b}$ & $-\mathrm{b}$ & $-\mathrm{b}$ \\
Streptococcus mutans & $6 \pm 1$ & 250 & $>500$ \\
Staphylococcus haemolyticus & $-\mathrm{b}$ & $-\mathrm{b}$ & $-\mathrm{b}$ \\
Streptococcus faecalis & $-\mathrm{b}$ & $-\mathrm{b}$ & $-\mathrm{b}$ \\
Streptococcus intermedius & $-\mathrm{b}$ & $-\mathrm{b}$ & $-\mathrm{b}$ \\
Streptococcus pyogenes & $-\mathrm{b}$ & $-\mathrm{b}$ & $-\mathrm{b}$ \\
Streptococcus uberis & & & \\
Gram-negative bacteria & & 500 & $>500$ \\
Escherichia coli & $4 \pm 1$ &
\end{tabular}

${ }^{\mathrm{a}} \mathrm{MIC}$ values with $\mathrm{CHX}$ were ranged for all strains from 7.81 (S. aureus) to 3.9 (E. coli) $\mu \mathrm{g} / \mathrm{mL}$

${ }_{(-)}$strain that resulted no sensitive with preliminary $\mathrm{KB}$ antimicrobial test $\varnothing=0 \mathrm{~mm}$, conc. $1000 \mu \mathrm{g} / \mathrm{mL}$

concentrations of the compound, inoculated with the bacterial strains as previously described for MIC and $\mathrm{MBC}$ evaluation, was incubated at $37^{\circ} \mathrm{C}$ for 6 days to permit the biofilm formation. The plate samples were subsequently washed three times with Phosphatebuffered saline $\mathrm{GIBCO}^{\circ} \mathrm{PBS}$ (ThermoFisher) to eliminate planktonic cells; thus, the biofilm was stained with $100 \mu \mathrm{L}$ of $0.1 \% w / v$ of crystal violet solution (Microbial, Uta, Italy) for $10 \mathrm{~min}$ at $25{ }^{\circ} \mathrm{C}$. After three washes with PBS solution, $200 \mu \mathrm{L}$ of $30 \% \nu / v$ acetic acid was added in every well to solubilize the dye from the bacterial biomass. The biofilm amount was measured with a plate reader spectrophotometer (SLT-Spectra II, SLT Instruments, Germany) at $450 \mathrm{~nm}$. The experiment was performed in triplicate and the MBIC represented the lowest concentration showing a $450 \mathrm{~nm}$ absorbance comparable with negative control, > 95\% (sample without bacteria).

\section{Cell line and viral infection}

A549 cells were propagated in DMEM $\left(\right.$ Gibco $\left.^{\mathrm{mm}}\right)$ supplemented with $10 \%$ Fetal Bovine Serum (E.U.-approved, South America Origin, Gibco ${ }^{\mathrm{mt}}$ ) and $1 \%$ penicillin/ streptomycin (Euroclone ${ }^{\circ}$ ). Cells were incubated at $37^{\circ} \mathrm{C}$ in humidified atmosphere of $5 \% \mathrm{CO}_{2}$ and $95 \%$ air. For production of vRNA, A549 cells were infected with Influenza virus A/Puerto-Rico/8/34 $\left(\mathrm{H}_{1} \mathrm{~N}_{1}\right)$ strain (IAV/ $\mathrm{PR} / 8 / 34$ ) with a multiplicity of infection of 5 . Five hours after infection, total RNA was isolated using the RNeasy Kit (Qiagen). 


\section{Cytotoxicity assay}

The effect of AE on A549 cells proliferation was determined in 96-well plates (Spectra Plate, PerkinElmer). Cells were seeded at initial density of $10^{5}$ cells $/ \mathrm{mL}$ and cultured in DMEM $\left(\right.$ Gibco $\left.^{\mathrm{rm}}\right)$ supplemented with $10 \%$ Fetal Bovine Serum (E.U.-approved, South America Origin, Gibco $^{\mathrm{rm}}$ ) and $1 \%$ penicillin/streptomycin (Euroclone ${ }^{\circ}$ ), in the presence or absence of serial dilutions of extract (ranging from $100 \mu \mathrm{g} / \mathrm{mL}$ to $0.03 \mu \mathrm{g} / \mathrm{mL}$ ). Camptothecin was used as positive control Table 2. Plates were incubated for $72 \mathrm{~h}$ at $37{ }^{\circ} \mathrm{C}$ in humidified atmosphere of $5 \% \mathrm{CO}_{2}$ and $95 \%$ air. Cell viability was determined adding PrestoBlue $^{\mathrm{mat}}$ Cell Viability Reagent (Invitrogen). Following $1 \mathrm{~h}$ incubation at $37{ }^{\circ} \mathrm{C}$, relative fluorescence was read with a Victor3 (Perkin Elmer). The percentages of cell viability were calculated on the amount of living cells in extract treated cells relative to untreated control cells (defined as $100 \%$ viability). Cytotoxicity graph was then generated by plotting percentage of cell viability versus concentration of extract. The concentration required to reduce cell growth by $50 \%\left(\mathrm{CC}_{50}\right)$ was calculated using regression analysis of cytotoxicity curves.

\section{Luciferase reporter gene assay for measuring IFN- $\beta$ induction}

The luciferase reporter gene assay was performed as previously described [37]. Briefly, A549 cells $\left(5 \times 10^{4}\right.$ per well) were transfected with T-Pro P-Fect Transfection Reagent (T-Pro Biotechnology, Twin Helix) and with the construct pGL IFN- $\beta$ luc. Twenty-four $h$ after transfection, cells were additionally transfected with Influenza virus $\mathrm{A} / \mathrm{PR} / 8 / 34\left(\mathrm{H}_{1} \mathrm{~N}_{1}\right)$ and incubated for further $6 \mathrm{~h}$ at $37{ }^{\circ} \mathrm{C}$ with $5 \% \mathrm{CO}_{2}$ in presence or absence of the extract. Then, cells were harvested with a Luciferase Harvesting Buffer (50 mM Na-MES pH 7.8, $50 \mathrm{mM}$ TrisHCl pH 7.8, $1 \mathrm{mM}$ dithiothreitol, $0.2 \%$ Triton X-100). The crude cell lysates were clarified by centrifugation and $50 \mu \mathrm{L}$ of cleared lysates were added to $50 \mu \mathrm{L}$ of Luciferase Assay Buffer (125 mM Na-MES $\mathrm{pH}$ 7.8, $125 \mathrm{mM}$ Tris- $\mathrm{HCl} \mathrm{pH}$ 7.8, $25 \mathrm{mM}$ magnesium acetate, $2.5 \mathrm{mg} / \mathrm{mL} \mathrm{ATP)} \mathrm{in} \mathrm{a} \mathrm{white} \mathrm{96-well} \mathrm{plate}$ (OptiPlate, PerkinElmer). Immediately after addition of $50 \mu \mathrm{L}$ of $1 \mathrm{mM}$ D-luciferin into each well, the luminescent signal was measured in Victor3 luminometer (Perkin Elmer). The relative light units measured were

Table 2 Cell growth inhibition of A549 cell line by plant extract. Data shown are the mean \pm SD of three independent experiments performed in duplicate samples

\begin{tabular}{lc}
\hline Extract/compound & ${ }^{\mathrm{a} C C_{50}(\mu \mathrm{g} / \mathrm{mL})}$ \\
\hline $\mathrm{AE}$ & $>100$ \\
Camptothecin & $0.54 \pm 0.15$ \\
\hline${ }^{a}$ Extract/compound concentration required to reduce cell growth by $50 \%$
\end{tabular}

normalized as the fold activity of the unstimulated control. Each assay was carried out in triplicate.

\section{EBOV VP35 luciferase reporter gene inhibition assay}

The above described luciferase reporter gene assay was also performed for evaluating the IFN- $\beta$ induction inhibition mediated by EBOV VP35 protein. When the pcDNA3-ZEBOV-VP35 was used as control, it was cotransfected with the pGL IFN- $\beta$ luciferase plasmid. Inhibition of luciferase expression was indicated as percentage of induced control. Each assay was carried out in triplicate.

\section{HPLC-DAD-ESI/MS analysis}

The AE was analyzed as previously reported [43]. Briefly, the solvents were: (A) $0.1 \%$ formic acid, and (B) acetonitrile. The elution gradient established was isocratic $15 \%$ B for 5 min, 15-20\% B over 5 min, 20-35\% B over $10 \mathrm{~min}, 35-50 \%$ B over $10 \mathrm{~min}, 50-60 \%$ B over $2 \mathrm{~min}$, isocratic $60 \% \mathrm{~B}$ for $5 \mathrm{~min}$ and re-equilibration the column, using a flow rate of $0.5 \mathrm{~mL} / \mathrm{min}$. Double online detection was carried out in the DAD using $280 \mathrm{~nm}$ and $370 \mathrm{~nm}$ as preferred wavelengths and in the MS operated in the negative ion mode. The phenolic compounds present in the samples were identified according to their UV and mass spectra and by comparison with commercial standards, when available.

\section{Data analysis}

Data are expressed as mean \pm SD from three independent experiments. The analysis average of the treatment was determined using $t$-student (Prism 6 program), and the data were compared using the $p$ values: $p<0.05$ was considered statistically significant.

\section{Results}

Antimicrobial susceptibility testing and citotoxicity of $A$. microcarpus extract

When tested on 13 different microorganisms, AE showed an inhibitory effect on Gram-positive bacteria while lower inhibition was observed on the Gram-negative bacteria $E$. coli (Table 1). When tested for antibiofilm activity, AE showed an interesting effect on various bacterial strains (E. coli, S. aureus, S. haemolyticus and B. clausii). The MBIC was shown to be, except for $B$. clausii, 2 or 4 fold lower than the respective MIC value, Fig. 1. This result suggests that $\mathrm{AE}$ is able to counteract the biofilm formation by the probable presence of antiattachment or quorum quenching substances [44]. No activity was detected against yeasts (data not shown).

To evaluate the AE effects on the EBOV VP35 inhibition of the IFN activation, we first screened $\mathrm{AE}$ for eukaryotic cellular toxicity in order to determine the appropriate concentrations for the following luciferase 


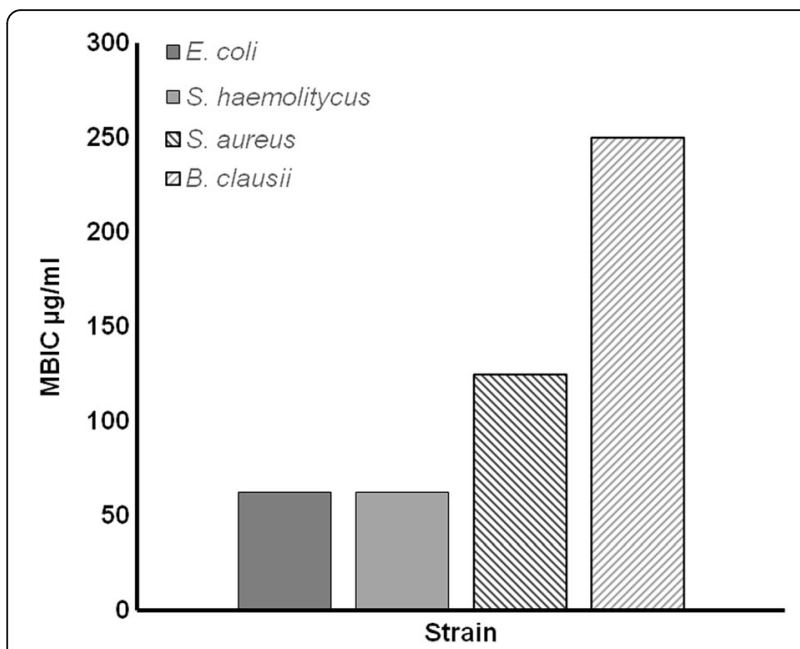

Fig. 1 Minimal biofilm inhibitory concentration (MBIC) on four bacterial strains resulted biofilm sensitive at $A$. microcarpus extract. $\mathrm{MBIC}$ represent the lowest concentration showing a $450 \mathrm{~nm}$ absorbance $>95 \%$ comparable with negative control, sample without bacteria (ABS, SD $\pm 15 \%$ ). The $\mathrm{CHX}$ showed a MBIC values ranged from 3.9 to $0.97 \mu \mathrm{g} / \mathrm{mL}$

reporter IFN- $\beta$ gene assays. Total $\mathrm{AE}$ showed no cytotoxic effects on A549 cells with a $\mathrm{CC}_{50}>100 \mu \mathrm{g} / \mathrm{mL}$. Camptothecin was used as positive control. Considering these results, the initial concentration of $30 \mu \mathrm{g} / \mathrm{mL}$ was chosen to investigate the effects of a possible increase of the dsRNA RIG-I-mediated IFN- $\beta$ induction.

\section{Potential antiviral activity of $A$. microcarpus}

EBOV VP35 is a validated drug target involved in several crucial processes for a successful viral replication and propagation. In order to study the $\mathrm{AE}$ capacity to potentiate the dsRNA-dependent RIG-I-mediated IFN- $\beta$ induction, the luciferase reporter gene assay and the VP35 inhibition assay previously described were performed [37]. Results showed that AE was capable to significantly potentiate ( $p$ value <0.05) dsRNA-dependent RIG-Imediated the IFN $-\beta$ production at the concentrations of $10 \mu \mathrm{g} / \mathrm{mL}$ and $3 \mu \mathrm{g} / \mathrm{mL}$ (Fig. 2). Noteworthy, AE did not stimulate the innate antiviral response when tested in the absence of a vRNA stimulus (data not shown).

Given the ability of increasing IFN production following dsRNA stimulation shown by AE in the IFN- $\beta$ induction assay, we then investigated whether such increase of IFN-induction was adequate to subvert the blockade of the signaling cascade mediated by EBOV VP35. For this reason, the same AE concentrations were tested in dsRNA-dependent RIG-I-mediated IFN- $\beta$ induction system in the presence of EBOV VP35.

Results showed that AE significantly reverted the EBOV VP35 inhibition of the vRNA induced IFN response at concentrations of $3-0.1 \mu \mathrm{g} / \mathrm{mL}(3 \mu \mathrm{g} / \mathrm{mL}$ $p<0.05,1$ and $0.3 \mu \mathrm{g} / \mathrm{mL} p<0.05,0.1 \mu \mathrm{g} / \mathrm{mL}$ $p<0.001$ ) (Fig. 3).

\section{Characterization of phenolic compounds in A. microcarpus leaves extract}

The HPLC phenolic profile of $A$. microcarpus leaves extract, recorded at wavelength, $\lambda=330 \mathrm{~nm}$, is shown in Fig. 4. Data on retention times, $\left(t_{\mathrm{r}}\right)$, wavelengths of maximum absorbance $\left(\lambda_{\max }\right)$, pseudo-molecular ions $\left([\mathrm{M}-\mathrm{H}]^{-}\right)$, diagnostic fragments and tentative identification for each peak of the phenolic compounds detected are listed in Table 3. Results showed a phenolic profile similar to the previously described in A. microcarpus flowers [43] but, in this case, the major peak 2 occurs with luteolin-6$\mathrm{C}$-glucoside. Moreover, cichoric acid and cumaril exosa malic acid were not present in flowers extract.

\section{Discussion}

Asphodelus microcarpus leaves showed the ability to inhibit some Gram-positive and, with lower potency,

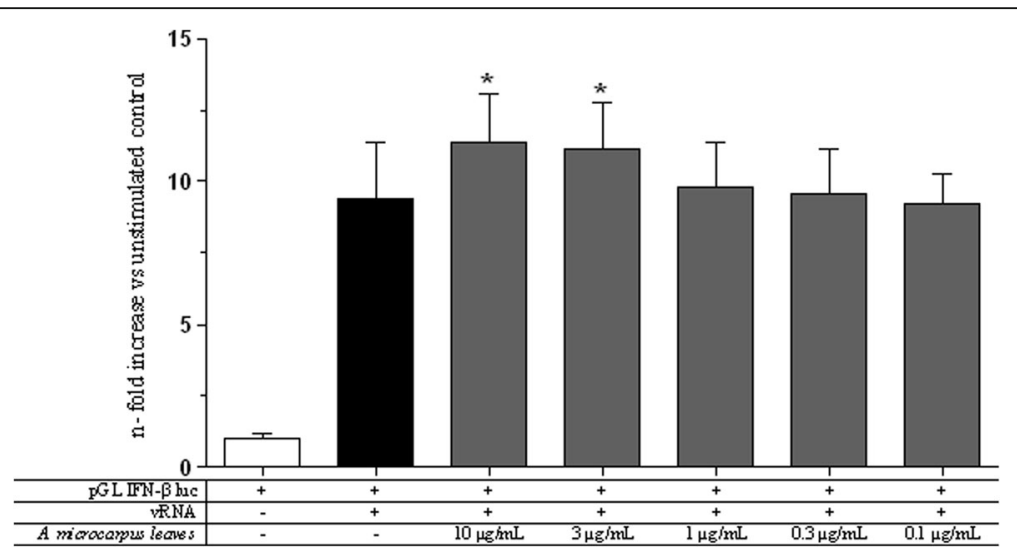

Fig. 2 A. microcarpus leaves extract effects on IFN- $\beta$ induction. The AE was tested in a RIG-I-mediated IFN- $\beta$ induction system with vRNA stimulation. Results are shown in $n$-fold compared to unstimulated control (* $p$ value $<0.05$ ) 


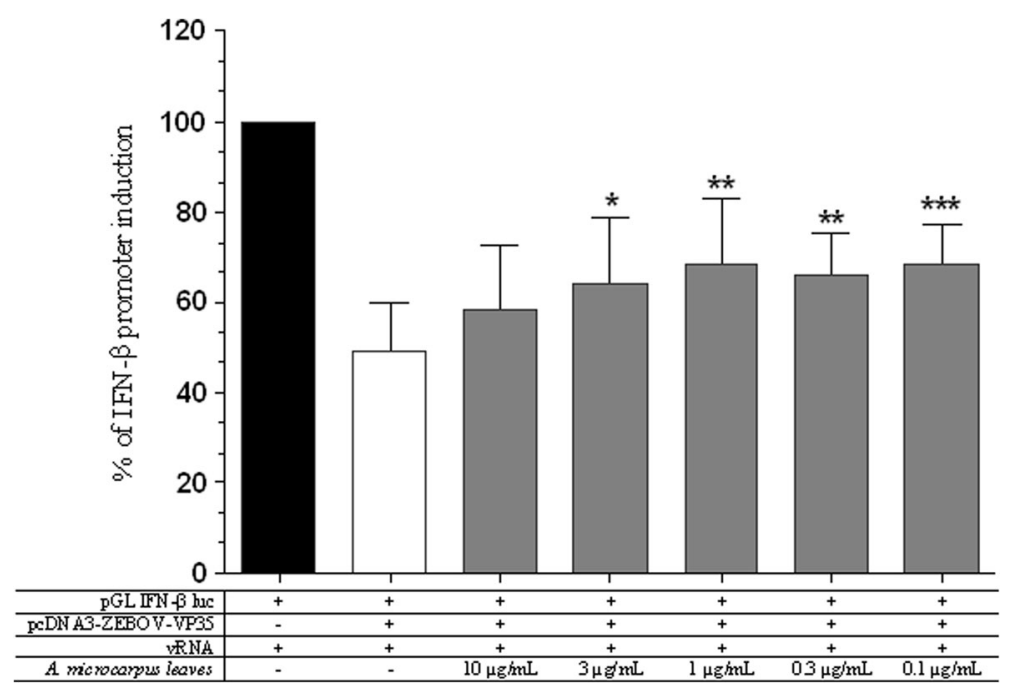

Fig. 3 A. microcarpus leaves extract effects on IFN- $\beta$ induction inhibition of EBOV VP35. The extract was tested in RIG-I-mediated IFN- $\beta$ induction system in presence of EBOV VP35 inhibition. Results are shown as the percentage of IFN- $\beta$ promoter induction $\left({ }^{*} p\right.$ value $<0.05$, ${ }^{* *} p$ value $<0.01$, *** $p$ value $<0.001)$

Gram-negative bacteria but displayed no activities against Streptococci spp. and yeasts.

If we compare two Gram positive bacteria groups, our data demonstrate that $\mathrm{AE}$ extract is more active with aerobic strains (Staphylococcus) than with facultative anaerobic strains (Streptococcus). Following previous reports, these differences in sensitivity could be due to different cytoplasmic cell membrane composition. In fact, flavonoids are able to interfere with different cell membrane compounds in lipid bilayers and they may control the arrangement of membrane proteins with the formation of functional complexes responsible for cell signal transduction and the regulation of the metabolism [45]. In this context by using luteolin, different authors reported decreases in ATPase activity and in the production/secretion of $\alpha$-toxin in Staphylococcus aureus [46, 47].

The antimicrobial activity of ethanolic extract from $A$. microcarpus tubers has been previously published [32]. Moreover, a previous study reported the antimicrobial

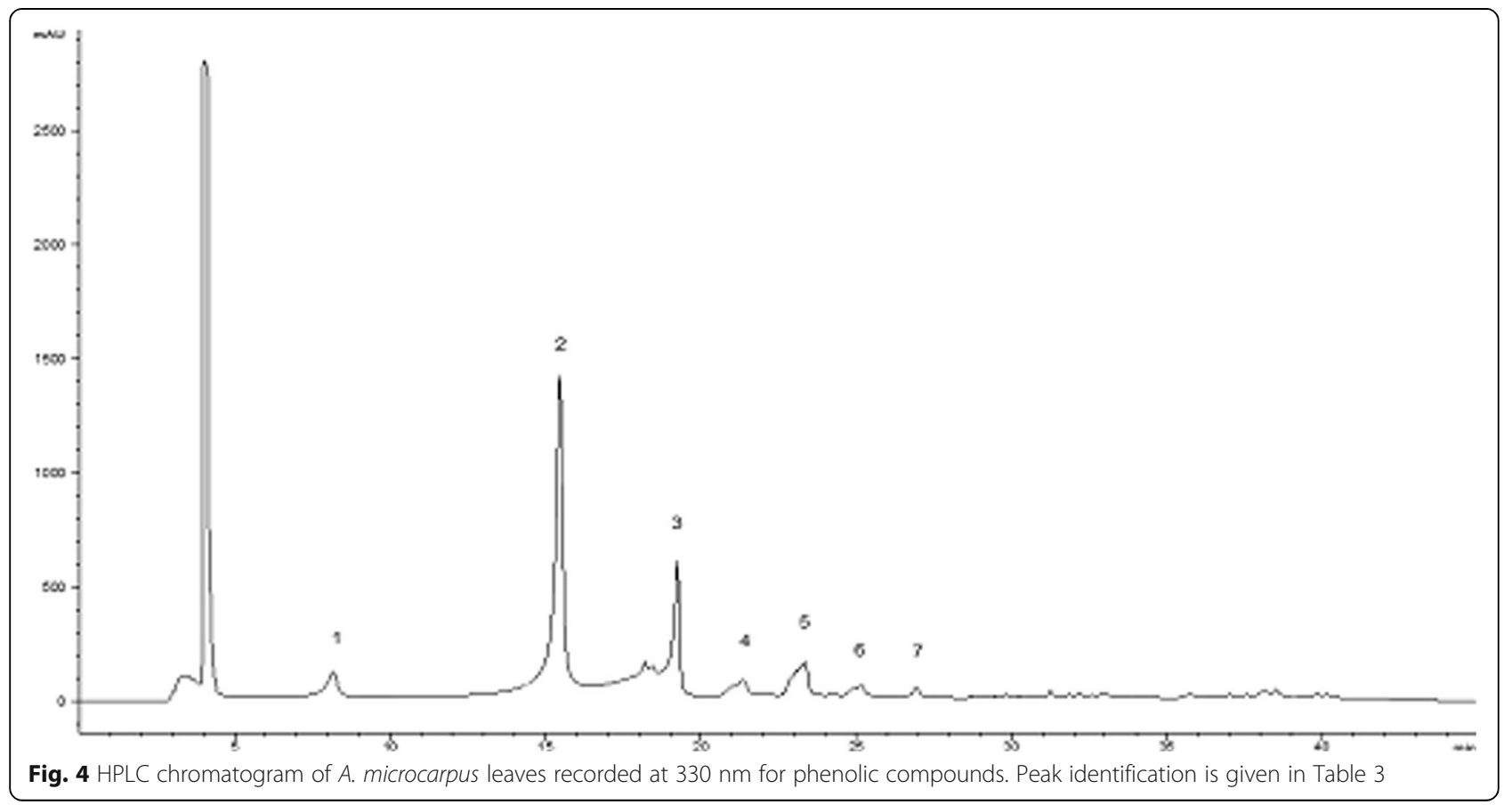


Table 3 Identification of polyphenolic compounds in A. microcarpus leaves extract by HPLC-DAD- ESI/MS analysis

\begin{tabular}{|c|c|c|c|c|c|}
\hline Peak & $\begin{array}{l}\mathrm{Rt} \\
(\mathrm{min})\end{array}$ & $\begin{array}{l}\lambda \max \\
(\mathrm{nm})\end{array}$ & $\begin{array}{l}\text { Molecular ion } \\
{[\mathrm{M}-\mathrm{H}]^{-}(\mathrm{m} / \mathrm{z})}\end{array}$ & $\begin{array}{l}\mathrm{MS}^{2}(\mathrm{~m} / \mathrm{z}) \\
(\%)\end{array}$ & Tentative identification \\
\hline 1 & 8.1 & 326 & 353 & $\begin{array}{l}\text { 191(100) } \\
354(50)\end{array}$ & 5-O-caffeoylquinic acid \\
\hline 2 & 15.4 & 350 & 447 & $\begin{array}{l}429(30) \\
357(94) \\
327(95) \\
447(100)\end{array}$ & Luteolin -6-C-glucoside \\
\hline 3 & 19.3 & 350 & 489 & $\begin{array}{l}429(11) \\
357(38) \\
327(91) \\
489(100)\end{array}$ & $\begin{array}{l}\text { Luteolin -6-C- } \\
\text { acetilglucoside }\end{array}$ \\
\hline 4 & 21.2 & 336 & 473 & $\begin{array}{l}311(100) \\
341(27) \\
283(17) \\
413(12) \\
429(3) \\
473(93)\end{array}$ & Cichoric acid \\
\hline 5 & 23.2 & 332 & 623 & $\begin{array}{l}623(100) \\
447(58) \\
429(38) \\
309(26) \\
417(24) \\
327(18)\end{array}$ & Luteolin-C-glucoside \\
\hline 6 & 25.1 & 332 & 441 & $\begin{array}{l}441(100) \\
213(48) \\
153(9) \\
195(8) \\
399(4)\end{array}$ & Cumaril exosa malic acid \\
\hline 7 & 27 & 336 & 285 & 285(100) & Luteolin \\
\hline
\end{tabular}

activities of methanolic extract of $A$. microcarpus leaves [35]. Our results indicated that ethanolic extract of $A$. microcarpus exhibited a different antimicrobial activity against E. coli, S. aureus and Candida albicans if compared with previous report [35]. It is considered that these differences depend on solvent material and extraction process used.

In the present study, MBIC test was carried out to evaluate the possible effects of $\mathrm{AE}$ on biofilm-mediated diseases: results showed an antibiofilm effect against some pathogens (E. coli, S. aureus, S. haemolyticus and $B$. clausii). Further studies are required to explain if the $\mathrm{AE}$ acts against biofilm formation through the quorumsensing pathway or it acts as an anti-attachment agent.

The discovery of small molecules able to reinforce the innate antiviral response when it is under viral attack is a novel and powerful approach against the inhibitory strategies carried out by highly pathogenic viruses such as EBOV through its VP35 protein. For this purpose, we tested $A$. microcarpus leaves extract to verify if it was capable to modulate the dsRNA-dependent RIG-Imediated IFN- $\beta$ induction. It is noteworthy that the AE did not stimulate the innate antiviral response when tested in the absence of a vRNA stimulus and showed the ability to potentiate the viral-induced IFN- $\beta$ production. Significantly, AE showed to be able to subvert VP35 effects at different effective concentrations with an almost similar efficacy between 3 and $0.1 \mu \mathrm{g} / \mathrm{mL}$ and a lower effect at the higher dose of $10 \mu \mathrm{g} / \mathrm{mL}$. It is worth of note that the window of AE efficacy in subverting VP35 inhibition of the IFN production is not completely overlapping with the $\mathrm{AE}$ dose-response IFN production shown in Fig. 2. Even if the reason of this is not clear at the moment, it is possible to speculate that the $\mathrm{AE}$ interaction with the IFN production pathways could be different in the presence of the viral protein. Smaller AE concentrations could be effective in reverting the VP35 inhibition but the IFN production system used could not be sensitive enough in the absence of VP35. The VP35 reverting activity, along with the fact that $A$. microcarpus leaves extract acts only under antiviral response induction, makes this plant extract very attractive for the development of an antiviral drug. Indeed, further studies will be required to: i) identify the constituent of the extract responsible for the antiviral activity and ii) determine the extract's mode of action that, presumably, interacts with one or more components of the RIG-I-mediated IFN signaling pathway increasing IFN production. In fact, as shown by HPLC-DADESI/MS analysis (Fig. 4), A. microcarpus extract is a complex matrix of several molecules, that could possibly act together inducing IFN production interacting with different cellular targets, as proposed for other synthetic compounds [48]. It is important to note that phenolic characterization of Asphodelus microcarpus leaves showed high presence of luteolin derivatives. These flavones were extracted from many plants and several studies showed their anti-inflammatory, antibacterial, antioxidant and anti-HIV activity and may be involved in AE biological activity [49-51].

In addition, luteolin has been shown to inhibit the kinase activity of TBK [52] a component of the RIG-I cascade. Hence, it is possible that either luteolin and/or luteolin-C-glucoside may modulate dsRNA-dependent RIG-I-mediated IFN- $\beta$ production. Further studies will be needed to investigate these possibilities. Overall, additional studies will be also needed to characterize extract fractions in order to identify the individual molecules with biological activity.

\section{Conclusion}

Nowadays, natural products appear to be an interesting solution against the emergency of the antibacterial resistance and immune-regulators. In this study, A. microcarpus extract has shown a useful antibiofilm effect that could have a crucial role against biofilm-mediated diseases. However, other studies will be needed to clarify $\mathrm{AE}$ active component as well as the $\mathrm{AE}$ mechanism in 
the biofilm formation and to verify if others bacteria are sensitive to AE.

Finally, given that EBOV VP35 is a paradigm protein for potent viral IFN-suppression, the present study represents an interesting starting point for further studies that should focus on: i) the study of the mechanism of action of $A$. microcarpus extract and its constituents in the dsRNA-dependent RIG-I-mediated IFN signaling pathway, in order to potentiate the innate immune response; ii) the design and synthesis of molecules as selective inhibitors/revertant of EBOV VP35 inhibition of IFN production. In the need for new available antiviral therapeutics of natural origin, A. microcarpus appears to be a promising starting point for the development of molecules with broad antiviral activity.

\section{Abbreviations}

AE: Asphodelus extract; $\mathrm{CHX}$ : Chlorhexidine digluconate solution; EBOV: Ebola virus; HCV: Hepatitis C virus; IFN: I interferon; KB: Kirby-Bauer; MBC: Minimum bactericidal concentration; MBIC: Minimal biofilm inhibitory concentration; MIC: Minimal inhibitory concentration; vRNA: viral RNA

\section{Acknowledgements}

The authors are grateful to Dr. Cecilia Loi (University of Cagliari) for plant authentication.

\section{Funding}

This work was partially supported by grants from Università di Cagliari. Aldo Frau was supported by RAS LR 07/2007 grant n. CRP-78711/ F72115000900002 and gratefully acknowledges Sardinia Regional Government for the financial support of his PhD scholarship (P.O.R. Sardegna F.S.E. Operational Program of the Autonomous Region of Sardinia, European Social Fund 20072013 - Axis IV Human Resources, Objective I.3, Line of Activity 1.3.1.).

\section{Availability of data and materials}

The datasets supporting the conclusion of this article are included within the manuscript.

\section{Authors' contributions \\ ADP and AF were involved in the design of this research, data collection and supervision. ADP, AF and FP were involved in plant collection and extraction. CS-B, AMG-P and ADP performed HPLC-DAD-ESI/MS analysis. VP, GO, AM, ET and AFr performed biological assays. All authors read and approved the final version of the manuscript. The authors alone are responsible for the content and writing of this article.}

\section{Ethics approval and consent to participate}

Not applicable.

\section{Consent for publication}

Not applicable.

\section{Competing interests}

The authors declare that they have no competing interests.

\section{Publisher's Note}

Springer Nature remains neutral with regard to jurisdictional claims in published maps and institutional affiliations.

\section{Author details}

'Department of Life and Environmental Sciences, University of Cagliari, Cittadella Universitaria, SS 554, Bivio per Sestu, I-09042 Cagliari, Monserrato, Italy. ${ }^{2}$ Grupo de Investigación en Polifenoles, Unidad de Nutrición y Bromatología, Facultad de Farmacia, Universidad de Salamanca, Salamanca, Spain. ${ }^{3}$ Department of Surgical Science, University of Cagliari, 09124 Cagliari, Italy.
Received: 1 June 2017 Accepted: 10 July 2017

Published online: 14 July 2017

\section{References}

1. Sharma SB, Gupta R. Drug development from natural resource: a systematic approach. Mini-Rev Med Chem. 2015;15:52-7.

2. Fang J, Liu C, Wang Q, Lin P, Cheng F. In silico polypharmacology of natural products. Brief Bioinform. 2017;1-19. doi: 10.1093/bib/bbx045.

3. Dahanukar SA, Kulkarni RA, Rege NN. Pharmacology of medicinal plants and natural products. Indian J Pharmacol. 2000;32:S81-118.

4. Cowan MM. Plant products as anti-microbialagents. Clin Microbiol Rev. 1999;12:564-82

5. Abdollahzadeh S, Mashouf R, Mortazavi H, Moghaddam M, Roozbahani N, Vahedi M. Antibacterial and antifungal activities of Punica granatum peel extracts against oral pathogens. J Dent (Tehran). 2011:8(1):1-6.

6. Pisano MB, Cosentino S, Viale S, Spanò D, Corona A, Esposito F, Tramontano E, Montoro P, Tuberoso CIG, Medda R, Pintus F. Biological activities of aerial parts extracts of Euphorbia characias. Biomed Res Int. 2016;2016:1-11.

7. Mocan A, Crisan G, Vlase L, Crisan O, Dan Cristian Vodnar AA, Raita O, Gheldiu A-M, Toiu A, Oprean R, Tilea I. Comparative studies on Polyphenolic composition, antioxidant and antimicrobial activities of Schisandra chinensis leaves and fruits. Molecules. 2014:19(9):15162-79.

8. Costerton JW, Stewart PS, Greenberg EP. Bacterial biofilms: a common cause of persistent infections. Science. 1999:21(284(5418):1318-22.

9. Mah TF, O'Toole GA. Mechanisms of biofilm resistance to antimicrobial agents. Trends Microbiol. 2001:9(1):34-9.

10. Lieberman D, Lieberman D. Pseudomonal infections in patients with COPD: epidemiology and management. Am J Respir Med. 2003;2(6):459-68.

11. Kumar S, Pandey AK. Chemistry and Biological Activities of Flavonoids: An Overview. ScientificWorldJournal. 2013;2013. Article ID 162750. 16 pages.

12. Pintus F, Spanò D, Corona A, Medda R. Antityrosinase activity of Euphorbia characias extracts. PeerJ. 2015;vol 3, article e1305. doi: 10.7717/peerj.1305.

13. Rosa A, Maxia A, Putzu D, Atzeri A, Era B, Fais A, Sanna C, Piras A. Chemica composition of Lycium Europaeum fruit oil obtained by supercritical $\mathrm{CO}_{2}$ extraction and evaluation of its antioxidant activity, cytotoxicity and cell absorption. Food Chem. 2017;230:82-90.

14. Rashed R, Medda R, Spanò D, Pintus F. Evaluation of antioxidant, antityrosinase potentials and phytochemical composition of four Egyptian plants. Int Food Res J. 2016;23(1):203-10.

15. Wahyuni TS, Tumewu L, Permanasari AA, Apriani E, Adianti M, Rahman A, Widyawaruyanti A, Lusida MI, Fuad A, Fuchino H, Kawahara N, Shoji I, Deng L, Aoki C, Hotta H. Antiviral activities of Indonesian medicinal plants in the east java region against hepatitis C virus. Virol J. 2013;259:1-9. doi:10.1186/ 1743-422X-10-259.

16. Esposito F, Corona C, Zinzula L, Kharlamova T, Tramontano E. New Anthraquinone Derivates as Inhibitors of the HIV-1 Reverse transcriptaseAssociated Ribonuclease H Function. Chemotherapy. 2012;58:299-307. doi: 10.1159/000343101.

17. Derksen A, Kühn J, Hafezi W, Sendker J, Ehrhardt C, Ludwig S, Hensel A. Antiviral activity of hydroalcoholic extract from Eupatorium perfoliatum $\mathrm{L}$. against the attachment of influenza a virus. J Ethnopharmacol. 2016;188: 144-52. doi:10.1016/j.jep.2016.05.016.

18. Bicchi C, Rubiolo P, Ballero M, Sanna C, Matteodo M, Esposito F, Zinzula L, Tramontano E. HIV-1-inhibiting activity of the essential oil of ridolfia segetum and oenanthe crocata. Planta Med. 2009;75:1331-5. doi:10.1055/s0029-1185546

19. Esposito F, Sanna C, Del Vecchio C, Cannas V, Venditti A, Corona A, Bianco A, Serrilli AM, Guarcini L, Parolin C, Ballero M, Tramontano E. Hypericum hircinum $\mathrm{L}$. components as new single-molecule inhibitors of both HIVreverse transcriptase-associated DNA polymerase and ribonuclease $\mathrm{H}$ activities. Pathog Dis. 2013;68:116-24. doi:10.1111/2049-632X.12051.

20. Xu L, Grandi N, Del Vecchio C, Mandas D, Corona A, Piano D, Esposito F, Parolin C, Tramontano E. From the traditional Chinese medicine plant Schisandra Chinensis new scaffolds effective on HIV-1 reverse transcriptase resistant to non-nucleoside inhibitors. J Microbiol. 2015;53:288-93. doi:10. 1007/s12275-015-4652-0.

21. Haller $\mathrm{O}$, Kochs $\mathrm{G}$, Weber $F$. The interferon response circuit : induction and suppression by pathogenic viruses. Virology. 2006;344:119-30. doi:10.1016/j. virol.2005.09.024

22. Ma DY, Suthar MS. Mechanisms of innate immune evasion in re-emerging RNA viruses. Curr Opin Virol. 2015;12:26-37. doi:10.1016/j.coviro.2015.02.005. 
23. Zinzula L, Tramontano E. Strategies of highly pathogenic RNA viruses to block dsRNA detection by RIG-I-like receptors: Hide, mask, hit. Antivir Res. 2013;100(3):615-35. doi:10.1016/j.antiviral.2013.10.002.

24. Zinzula L, Esposito F, Pala D, Tramontano E. dsRNA binding characterization of full length recombinant wild type and mutants Zaire Ebolavirus VP35. Antivir Res. 2012;93(3):354-63.

25. Bruni A, Ballero M, Poli F. Quantitative ethnopharmacological study of the Campidano Valley and Urzulei district, Sardinia, Italy. J Ethnopharmacol. 1997:57:97-124.

26. Schäfer $\mathrm{G}$, Kaschula $\mathrm{CH}$. The Immunomodulation and anti-inflammatory effects of garlic Organosulfur compounds in cancer chemoprevention. AntiCancer Agents Medicinal Chemistry. 2014;14:233-40.

27. Täckholm V. Students Flora of Egypt. 2nd ed. Cairo: Cairo University Press; 1974. p. 629-30

28. Sarri M, Mouyet FZ, Benziane M, Cheriet A. Traditional use of medicinal plants in a city at steppic character (M'sila, Algeria). J Pharm Pharmacognosy Res. 2014:2:31-5.

29. Loi MC, Maxia L, Maxia A. Ethnobotanical comparison between the villages of Escolca and Lotzorai (Sardinia, Italy). J Herbs Spices Medecinal Plants. 2005;11:67-84

30. El-Seedi HR. Antimicrobial Arylcoumarins from Asphodelus Microcarpus. J Nat Prod. 2007;70:118-20.

31. Ghoneim MM, Ma G, El-Hela AA, Mohammad AE, Kottob S, ElGhaly S, Cutler SJ, Ross SA. Biologically active secondary metabolites fromAsphodelus microcarpus. Nat Prod Commun. 2013;8:1117-9.

32. Ghoneim MM, Elokely KM, El-Hela AA, Mohammad AE, Jacob M, Radwan MM, Doerksen RJ, Cutler SJ, Ross SA. Asphodosides A-E, anti-MRSA metabolites from Asphodelus Microcarpus. Phytochemistry. 2014;105:79-84.

33. Nelson K, Lyles JT, Li T, Saitta A, Addie-Noye E, Tyler P and Quave CL. AntiAcne Activity of Italian Medicinal Plants Used for Skin Infection. Front Pharmacol. 2016;7:Article425.

34. Al-Kayali R, Kitaz A, Haroun M. Antibacterial activity of Asphodelin lutea and Asphodelus Microcarpus against Methicillin resistant Staphylococcus aureus isolates. Int J Pharmacognosy Phytochem Res. 2016:8(12):1964-8.

35. El-Ghaly E-SM. Phytochemical and biological activities of Asphodelus microcarpus leaves. J Pharmacognosy Phytochemistry. 2017;6(2):259-64.

36. Orrù G, Del Nero S, Tuveri E, Ciusa ML, Pilia F, Erriu M, Orrù G, Liciardi M, Piras V, Denotti G. Evaluation of antimicrobial-Antibiofilm activity of a hydrogen peroxide decontaminating system used in dental unit water lines. Open Dent J. 2010:4:140-6.

37. Cannas V, Daino GL, Corona A, Esposito F, Tramontano E. A Luciferase reporter gene assay to measure Ebola virus viral protein 35-associated inhibition of double-stranded RNA-stimulated, retinoic acid-inducible gene 1-mediated induction of interferon $\beta$. J Infect Dis. 2015;212:S277-81. doi:10. 1093/infdis/jiv214

38. Zhang X, Ao Z, Bello A, Ran X, Liu S, Wigle J, Kobinger G, Yao X. Characterization of the inhibitory effect of an extract of Prunella vulgaris on Ebola virus glycoprotein (GP)-mediated virus entry and infection. Antivir Res. 2016:127:20-31.

39. Sepandj F, Ceri H, Gibb A, Read R, Olson M. Minimum inhibitory concentration $(\mathrm{MIC})$ versus minimum biofilm eliminating concentration (MBEC) in evaluation of antibiotic sensitivity of gram-negative bacilli causing peritonitis. Perit Dial Int. 2004;24(1):65-7.

40. Langfield RD, Scarano FJ, Heitzman ME, Kondo M, Hammond GB, Neto CC. Use of a modified microplate bioassay method to investigate antibacterial activity in the Peruvian medicinal plant Peperomia Galioides. J Ethnopharmacol. 2004;94(2-3):279-81.

41. Wiegand I, Hilpert K, Hancock RE. Agar and broth dilution methods to determine the minimal inhibitory concentration (MIC) of antimicrobial substances. Nat Protoc. 2008:3(2):163-75.

42. Merritt $\mathrm{JH}$, Kadouri DE, and O'Toole GA. Growing and analyzing static biofilms. Curr Protoc Microbiol. 2005. doi: 10.1002/9780471729259.mc01b01s00.

43. Di Petrillo A, González-Paramás AM, Era B, Medda R, Pintus F, Santos-Buelga C, Fais A. Tyrosinase inhibition and antioxidant properties of Asphodelus microcarpus extracts. BMC Complement Altern Med. 2016;16(1):453. doi:10. 1186/s12906-016-1442-0.

44. Zhu J, Kaufmann GF. Quo vadis quorum quenching? Curr Opin Pharmacol. 2013:13(5):688-98

45. Tarahovsky YS, Kim YA, Yagolnik EA, Muzafarov EN. Flavonoid-membrane interactions: involvement of flavonoid-metal complexes in raft signaling. Biochim Biophys Acta. 2014;1838(5):1235-46. doi:10.1016/j.bbamem.2014.01.021.
46. Joung DK, Lee YS, Han SH, Lee SW, Cha SW, Mun SH, Kong R, Kang OH, Song HJ, Shin DW, Kwon DY. Potentiating activity of luteolin on membrane permeabilizing agent and ATPase inhibitor against methicillin-resistant Staphylococcus aureus. Asian Pac J Trop Med. 2016;9(1):19-22. doi:10.1016/j. apjtm.2015.12.004

47. Qiu J, Li H, Meng H, Hu C, Li J, Luo M, Dong J, Wang X, Wang J, Deng Y, Deng $X$. Impact of luteolin on the production of alpha-toxin by Staphylococcus aureus. Lett Appl Microbiol. 2011;53(2):238-43. doi:10.1111/j. 1472-765X.2011.03098x.

48. Luthra P, Aguirre S, Yen BC, Pietzsch CA, Sanchez-Aparicio MT, Tigabu B, Morlock LK, García-Sastre A, Leung DW, Williams NS, Fernandez-Sesma A, Bukreyev A, Basler CF. Topoisomerase II inhibitors induce DNA damagedependent interferon responses circumventing Ebola virus immune evasion. MBio 2017;8:e00368-e00317. doi.org/10.1128/mBio.00368-17.

49. Bedard KM, Wang ML, Proll SC, Loo Y-M, Katze MG, Gale M, ladonato SP. Isoflavone agonists of IRF-3 dependent Signaling have antiviral activity against RNA viruses. J Virol. 2012:86:7334-44. doi:10.1128/JVI.06867-11.

50. Kanadaswami C, Lee LT, Lee PPH, Hwang JJ, Ke FC, Huang YT, Lee MT. The antitumor activities of flavonoids. In Vivo (Brooklyn). 2005;19:895-910.

51. Seelinger G, Merfort I, Schempp CM. Anti-oxidant, anti-inflammatory and anti-allergic activities of luteolin. Planta Med. 2008;74:1667-77. doi:10.1055/s0028-1088314

52. Jeong $E$, Lee JY. Intrinsic and extrinsic regulation of innate immune receptors. Yonsei Med J. 2011:52(3):379-92. doi:10.3349/ymj.2011.52.3.379.

\section{Submit your next manuscript to BioMed Central and we will help you at every step:}

- We accept pre-submission inquiries

- Our selector tool helps you to find the most relevant journal

- We provide round the clock customer support

- Convenient online submission

- Thorough peer review

- Inclusion in PubMed and all major indexing services

- Maximum visibility for your research

Submit your manuscript at www.biomedcentral.com/submit

Biomed Central 